Меһмет Евкуран

Аағдарыс теологиясы және қоғамдық қозғалыс ретінде салафизм. Салафилік идеология және Ислам әлеміндегі ықпалы туралы сараптама

\section{Mehmet Evkuran}

On salafismas a crisis theology and social movement. An

Analysis on Salafi Ideology and It's Impacts on The Muslim

World

Меһмет Евкуран

Салафизм как кризис богословия и общественного Авижения. Анализ идеологии салафизма и ее влияние на мусульманский мир
Жаңа заманғы салафи қозғалысы түпнұсқаға қайту пікірін қорғайды әрі ислам әлеміндегі көне-жаңа барлық ерекшеліктерді қабылдамайды. Салафилар бойынша, бақытты ғасырда болмаған барлық нәрсе түбегейлі аАасушылық, әрі мәзһабтар сондай аАасуға апаратын жолдар. Салафи ойшылдар мәзһаб түсінігін қолАанбайды, олар салафи ұғымдарын таңдайды әрі салафр дәуірінде мәзһабтың болмағанын алға тартады. Осы себепті, салафилік Ислам әлемінің теологиялық әрі философиялық базасын радикал түрде қабылдамайды әрі ол діни түпнұсқаға оралуды дәріптейді. Ислам әлемінде салафилардың күшеуінің ең көп Сунниттерге ықпалы болған. Сунниттік жұмсақ әрі баурағыштық қасиетімен бүгінгі күні дәріптеу тұрғысынан дағдарысты бастан кешуде. Салафилік қуатты түрде Сунниттерге қарағанда ақиқатты иеленгенін айтуда. Екінші бір жағынан саяси қозғалыс ретінде салафилік Ислам әлеміндегі тепе теңАіктерді жояды әрі Ислам әлемін тұрақсыздандырады. Бұлан бөлек, мәдениетке қарсы қозғалыс ретінде салафилік бәдәуилікті қолдап, мәдени байлық, пен тарихи мұраға қарсы күрес жүргізеді. Аіни әрі архаикалық көзқарастарына қарамастан, салафилік жаңа заманғы саяси қозғалыс. Бұл мақаланың мақсаты - салафилік сана ерекшеліктерінің негіздерін анықтау әрі басты ұстанымдарын қарастыру.

Түйін сөздер: салафизм, ислам әлемі, мәзһабтар, сунниттер, мәдениет, өз болмысына оралу, саясат.

Modern salafi movement defends concept of return to essence/origin and refuses all of new or old identities in Muslim World. To salafism, everything was not be mentioned in the golden age (in Islamic literature is al-Asr as-Saadah) is inevitably herecy and Islamic sects (mazahib) are heretic roads. Salafist thinkers don't use the concept of mazhab; they prefer salafi and says that it was no mazhab in the salaf age, and they have no mazhab. Thus, salafism rejects the theological and philosophical accumulation of Muslim world radically and it means the theological essentialism. The most influenced structure in Muslim World is Sunnism by rising of salafism. Due to it's eclectic and surroinding structure, today Sunnism suffers from representation crises. Salafism strongly claims that it has truth of Sunnism. On the other hand salafism as a political movement, destroyes the political balances and destabilizes the Muslim World. Additionally, salafism as an anticulturalist movement, blesses the badawism and fights the cultural richness and historical heritage. Therefore despite of it's theological and archaic discourse salafism is a modern political movement. The aim of this article is to prove the basic structure of salafi mind and discuss it's main arguments.

Key words: Salafism, Muslim World, Islamic sects, Sunnism, culture, return to origin, policy.

Современное Авижение салафитов защищает концепцию возвращения к сущности/происхождения и отказывается от всех новых или старых илентичностей в мүсульманском мире. Аля салафизма все не упоминается в золотом веке (в исламской литературе аль-Аср ac-Saadah) неизбежно ереси и исламские секты (mazahib) являются еретическими Авижениями. Салафитские мыслители не используют понятия мазхаб; они предпочитают салафиты и говорят, что во времена салафитов мазхабов не было и что у них нет мазахбов. Таким образом, салафизм коренным образом отвергает теологическое и философское накопление в мусульманском мире, и это указывает на богословский эссенциализм. Наибольшее влияние в мусульманском мире получил суннизм с ростом саласризма. Благодаря своей эклектичной структуре, сегодня суннизм страдает от развала представительства. Салафизм утверждает, что он имеет истину суннизма. С Аругой стороны, салафизм как политическое Авижение подрывает политический баланс и дестабилизирует мусульманский мир. Кроме того, салафизм как антикультуралистское Авижение благословляет badawism и борется за культурное богатство и историческое наследие. Несмотря на их теологический и архаичный Аискурс, салафизм преАставляет собой современное политическое Авижение. Цель Аанной статьи состоит в том, чтобы рассмотреть основную структуру салафитской мысли и обсудить основные аспекты

Ключевые слова: салафизм, мусульманский мир, мазхабы, сунниты, культура, возвращение к происхождению, политика. 


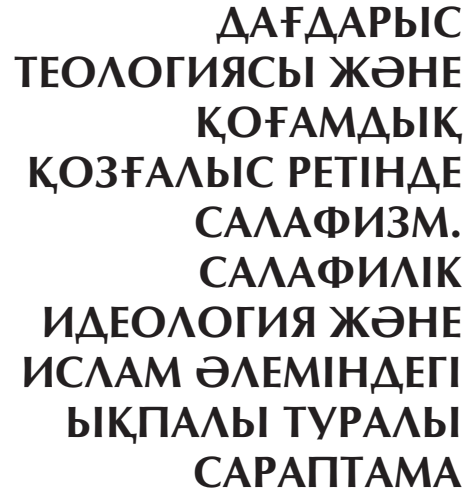

\section{Kipicne}

Соңғы кезеңде салафилік туралы әдебиеттердің қарасы молайды. Әрі батыста, әрі ислам әлемінде салафизм турасында танымал әрі академиялық жарияланымдарда да айтарлықтай өсу бар. Бұның негізгі себебі, ислам әлемінде орын алып отырған саяси мәселелер. Исламның ақиқатын иелену үшін күрес жүргізген дәстүрлі түсінік түрлері арасындағы жарыс та қарқын алуда. Айталық, Әхлі сүннет танымы, шегі қалай белгіленетіні, оған кімдер өкілдік ететіні, мәзһаб болып саналып, саналмайтыны, негізгі ұстанымдарының нелер екендігі секілді тақырыптар қайта таласқа түсе бастады. Осы тұрғыда салафиттік ең көп сөз етілетін ұғымға айналды. Салафизм Ислам әлеміндегі дәстүрлі мекемелердің (медресе, дәріс алқалары, халыққа ашық уағыздар т.б.) жанында жаңа заманғы байланыс құралдарын (теледидар, интернет, БАҚ және т.б.) да қолданылуда, әсіресе Сунниттік жағрапияда халық арасында жайылуда әрі жүргізген үгіт әдістерімен өздеріне жақтастар табуда жетістікке жетуде.

Шииттер мен Сунниттік қатынастар өзіне тән тарихи әрі саяси арнасында үнемі бір тепе теңдікке жетуді білген. Бұл жерде екі жақты да ұстанатындардың саяси санасы мен бюрократиялық мұрасы барынша ықпалды. Мемлекеттік қабылдауға ие парсылар мен түрік билігі келісімге келуге мүмкіндік берген саяси ақыл арқылы аймақтағы шиит - суннит тепе теңдігін сақтай алған. Алайда, Сунниттік әлемде салафиттіктің алға шығуы осы қатынастардың радикалды түрде бұзылуына жол ашқан.

Саяси пайымы әрі қолданған тілі «такфир» әрі дұшпандыққа негізделген және «өлгенге дейін жихад» ұстанымын мұсылман қоғамы ішінде ішкі соғыс ұстанымы ретінде жүзеге асырған осы түсінік әсілі саяси да емес. Неге десеңіз, саяси ойлау келісімге келуді, ортақ мүддеге жұмылуды және сыпайылықты қамтиды. Жаһандық күштердің тарихтан келетін Иран Тұран соғысын жаңартуға шамасы келмегені, соған сай араб қаржысынан қолдау табатын салафи топтар арқылы осы мақсаттарына сәл де болса жеткені байқалады. Халықаралық қатынастар мен ғаламдық саясат тұрғысынан қарағанда, салафиттік белсен- 
ді топтардың кезеңдік әрі аймақтық тұрақсыздық тудырып, Ислам әлемінде жүргізілетін операцияларға қолданылатыны көзге түседі.

\section{Салафиттердің теологиялық саяси тен- денциясы}

Салафиттік пікір нақты түрде Шииттерге қарсы. Бұл жерде салафиттерге шабыт қайнары ретінде Ибн Таймия пікірлерінің ықпалы барынша үлкен. Белгілі болғанындай, Ибн Таймия Харрандық. Ислам әлемінің сол мезгілдердегі хаостық жағдайы табиғи түрде оған да әсер еткен. Бір жағынан Моңғол шапқыншылығы, екінші жағынан Крест шабуылдары нәтижесінде анағұрлым сенімді жер ретінде Мысырға орналасқан. Құлдырау кезеңінің ойшылы ретінде Ибн Таймияның салафи пікірге деген ықпалы қозғалысқа теориялық әрі теологиялық терең астар беруінде жатыр. Оның бойынан құлдырау кезеңі ойшылдарына тән ойлау күйзелісін байқауға болады. Бұл кезеңдерде ойшыл сол кезеңдегі әлем жағдайы мен сол кезеңнің мәселелеріне қаншалықты сергек қараса, жүгінген тілі де соған сай ойлау жүйесіне негізделіп, соншалықты өткір бола түседі. Ибн Тәймия расында терен әрі сергек ойшыл. Алайда, сұңғылалығын Ислам қоғамының мәсеелерінің шешімінде реакцияшыл әрі радикал үлгі жетілдіру тұрғысында шоғырландырған.

Оның көзқарасы мынау еді: Исламның ең кемел дін екендігіне әрі Алла бұл дінге сенушілерге дүниеде және ақыретте жеңісте уәде еткеніне қарағанда, орын алған қорлық пен қайғының себептерін осы діннің тәлімінен бас тартқан, талаптарын орындамаған мұсылмандардан іздеу керек. Адасу теологиясын анықтауға тырысқан ойшылымыз жауапты ретінде тасаууыф, философия және кәламды атайды. Әрі салаф сеніміне қайтып, таза дін түсінігін негіздеуге тырысады.

Мықты ойшыл әрі шебер пікір таластырушы болған Ибн Таймия философтардың өзін жолда қалдыратындай деңгейде философия мен қисын білген. Білімін ықпалды әдіспен қолдана алған. Аристотель қисынына қарсы оймен жазған мәтін (Нақзул мантық) логика мәселесінде тәкпірші емес, философиялық сын болуымен назар аудартады. Қазіргі салафилар болса, Ибн Таймияның философиялық таластарда көрсеткен талпыныстарына емес, тұжырымдаған нәтижелерге қарауда. Бұл бөлімдердің үлкен ойлау тарихына енген таластары бір аят не бір хадис оқып, нәтижелендіру әрекеттері, олардың өзара әңгімелесуге, таласуға әрі сөйлесушіні түсіну- ге қаншалықты жабық екендігін байқатқан. Бұл әрекет бұдан бөлек ақиқатты иелену сезімінің ең дөрекі түрі. Ақиқатты иеленуіңіз мүмкін, алайда бұл сенім сізді сол үшін таласқа түсуден, философияға салынудан шеттетпейді. Бұл жерде бұдан бөлек нәрсе мәдениет жауластығы. Таласу, тыңдау, өзін танытқысы келу, сынға ашық болу т.б. Бұлардың барлығы шын мәнінде мәдениетті қалыптастырушы әрі оны жанды етіп ұстап тұрушы құндылық. Ал анығында ақиқат жаңылысуының жанына мәдениетке деген жауластықты қояр болсаңыз, әлемдегі ең бір ұнамсыз қосынды шығады. Діни насстардың осындай пішіндегі қолданысы салафиттердің ойлағандай емес, салафқа (бұрынғыларға) тән емес нәрсе.

Мәселелерге насстарды қолданып шешім іздеу, кейіннен жүйеленген іс. Құран аяттарының теологиялық және құқықтық мәселелерді шешуде негіз ретінде қолданылуы, мәзһабтардың қалыптасуынан кейін жүйеленген. Сахабаның Құранға көзқарасы сірә бұлай болмаған. Олар «талас-тартысқа аятты қолдануға» мейлінше жатсынып қараған. Құндылықтар жүйесі ретінде насстардың мақсаты мен мағынасын терең игергендіктен, көзқарастарында және іс әрекеттерінде көбіне қоғам пайдасы мен рационалдық себептерге сүйенетін. Жасаған барлық іс пен айтқан әр сөз үшін дәлел ретінде насс талап етпейтін. Бұл мәселе өте маңызды. Насстарды тек сырттай оқып, әсіре қолданып, олардың мақсаттарына және қамтыған құндылықтармен сәйкеспейтін көзқарас пен іс-әрекеттер тұжырымдау мәтіннің идеологиялық қолданысының табиғиланған мәзһабтар кезеңінде жүйеленген. Салафилық мәзһабтар ұрынған қателерді қайталамау үшін жорамалға қарсы шығып, Құранның идеологиялық жорамалдануына және мағынасын айналдыруға қарсылық танытуда. Жорамал мен көзқарасқа жүгінбестен, насстардың сөздеріне жүгінудің ақиданы саф түрде қорғаудың жолы екендігі ойға алынады.

Қазіргі заманғы салафи көзқарасты түсіндіретін мәтіндерде де осы классикалық ұстаным үлкен мөлшерде сақталуда. Сауд Арабия мүфтілерінен Абдулазиз ибн Баз тарапынан алғысөзі жазылған бір мәтінде ислам ақидасы, Әхлі сүннет ақидасымен теңестіріліп, негізгі ерекшеліктері тізіп көрсетілген. Бұлардың арасында ақиданың оңай әрі түсінікті болуына қатысты мыналар айтылған: «Ол оңай әрі Күннің анық көрінгеніндей ап-анық ақида. Одан қандайда бір жабықтық, түсініксіздік немесе қойыртпақтық жоқ. Сөздері анық, мағынасы түсінікті. Оларды ғалым немесе жай халықтан бәрі: үлкен кіші бәрі 
де түсінеді. Расул Алла оны тап таза, кіршіксіз қалпында жеткізген». Сенімнің анық екендігіне баса назар аударуы ислам ойшылдарының ислам дінінің адам жаратылысына сай екендігіне тән айтқандарымен ұқсастық байқатуда.

Салафи сөйлемде өткен «ақиданың ашық әрі оңай екендігіне» баса назар аударту насстарды ақылға салу мен оларды жорамалдау керек емес деген мағынаны білдіреді. Бұл бойынша Алла тура жол ретінде жіберген дінді ашық, түсінікті әрі оңай еткен. Егер онда бір қиындық болса, тура жол мен рақым ретінде сипаттауына қажеттілік болмас еді. Бұдан гөрі жорамал мен насстарды түсіндіруді мұрат етуі тұрғысынан ақиданың ашықтығы пікірмен қайшы түсуде. Онсыз да анық нәрсені түсіндіре алмайсыз. Ол болса түсіндіру мен жорамалдау деген атпен оны ластайды, қойыртпақтайды әрі адам танымайтындай күйге түсіреді. Салафи сөйлемнің жорамалға әрі жорамалдан туған нәрселерге деген көзқарасындағы қаталдықтың себебі түсінікті болуда. Спекуляцияға сүйенетін философия, ақылды насстардың айшықталуында өлшем деп санайтын кәлам, жоғарғы деңгейде жорамалға жүгінген тасаууыф. Бұлардың барлығы салафия көзқарасында ақиданы қойыртпақтайтын жолдар.

Ибн Тәймия кезеңінде Суннит шиит қатынастары барынша салқындаған. Шииттердің Моғолдармен келісіп, Сунниттерді жалғызсыратты деген пікір Сунниттердің ортасында айтарлықтай дүрдараздық тудырған. Осы салқындықтың бір белгісі ретінде Ибн Тәймия Шииттерді кәпір деп айыптайтындай дәрежеде еңбектер жазған. Салафиттің көзқарастағы Шииттерге деген теріс пиғыл осыдан негіз алады. Екінші бір жағынан Араб идеологиясы ретінде салафиттықтың саяси әрі теология ретінде адасқан деп қабылдаған Шииттерге қалай қарайтынын болжау аса қиын емес. Бұның тамыры Әмәуилер кезеңінде төбе байқатқан, алайда хадисшылар идеологиясында қай кезде де орнын тапқан «арапшылдық» идеясына сүйенуде. Құрайыштың саяси артықшылығын теологиялық дәлелдерге жүгініп күшейткен Араб ақылы саясат жолымен үкім беруді өзі үшін табиғи құқық ретінде көре бастады. Ал керісінше, саясат есіктерінің өздеріне жабық екенін көрген араб емес мұсылмандар басқа салаларға бет түзеді.

Мәуалидың (бұл ұғым араб емес мұсылмандар, әсіресе түріктер мен парсылар үшін қолданылады) өз қабілетін көрсету үшін бет түзеген салалардың алдыңғы қатарында ілім мен өнер тұрды. Осы шеңберде араб жұртының ілімді шеттетпегені, алайда ілімнен түсінгендері мүлдем басқа нәрсе болғандығын айтып кеткен жөн. Мәуалидың санасында ілім, ақылға салу және адам жасампаздығын көрсететін философия, өнер, теология және т.б. ға тең түссе, араб ақылы үшін ілім нақылдан тұрады. Ілім ұғымына бұл көзқарас мәдени парадигмалардың түрлі жұмыс істегенін көрсетеді. Тура осы себеппен хадисшілер қозғалысы тереңінде араб культурализмін алып жүруді міндетіне алса, Рәйшілдер бағытындағылар болса, философия, кәлам мен тасаууыф жолымен мәуалидың мәдени құндылықтарына бір сала ашу рефлексі байқалады. Осы себепті әхлі Хадис нақылшылдықты өсіріп, «дін нақылдан тұрады» деген дәлелге жүгінсе, бұрмаланған әдістеме деп қабылдағандықтан жорамалға мейлінше қарсылық танытады. Саяси ретте Араб билігін мойындамаған елдердің арабтар арқылы исламға деген дұшпандықтарының бір белгісі ретінде көрген әхлі рәй өнімдерін (кәлам, философия, тасаууыф, өнер т.б.) адасушылық деп санайды. Салафиттықтың кәлам, философия және суфизмге деген дұшпандығының астарында көне араб-мәуали қақтығысының ұмытылған іздері орын алғанын айтуға болады.

Әсілі салафтық идеология Шииттер жайында не ойласа, Сунниттік мәзһабтар туралы да соған ұқсас ойларға ие. Тасаууыф философия және кәламмен араласып, тұнығын лайлағандықтан, Сунниттік әлемнің теологиялық базасына да адасушылық деген көзбен қарайды. Тасаууыфты таза ширк деп қабылдаған салафия суфи бейнелерге орын беретін барлық мәдениеттерге қарсы. Сунниттік кәламның маңызды тамыры Матуридилікті де Мүржияның жалғасы деп сипаттайтын қазіргі заманғы салафиттер Сунниттердің екінші бір кәлам тармағы Әшғарилар үшін де осылай ойлайды. Ислам қоғамында пайда болған қозғалыс ретінде Мүржияның иман танымы, иман-амал қатынасына көзқарасы, күнәға көзқарасы секілді мәселелер мұсылман қасиетіне анағұрлым бейімделгіштік әрі кең мазмұн қосу талпыныстарынан алыс емес. Бұл әдіс ислам әлемінде Харижи қозғалыстың теологиялық қысымын теңшеп, жамағатқа рахат пен кеңдік қамтамасыз етті. Екінші жағынан мәуали ретінде көрінген әрі ислам ішінде паналаушы секілді қабылданған араб тегінен емес мұсылмандардың абырой мен бағасын арттырды. Мүржияның иманды амалдан ажыратып әсірелеуінің әлеуметтік мәдени әрі саяси тұрғыдан білдірген мағынасы қоғамдық тепе-теңдіктің керектігінің бір белгісі. Неге десеңіз, мауали амал арқылы 
емес, тек иман секілді ішкі және дерексіз құндылық арқылы қалаған теңдік пен абыройға қол жеткізе алатын еді.

Қысқаша айтқанда, салафиттік идеология Батыстағы анархистік ағымдарда байқалған бір ұқсасын ислам әлемінде көрсетуде әрі қоғамға, тарихқа, мәдениетке, өнерге, философияға т.б. бәріне қарсы көзқарасты ұстануда. Салафиттік мойындамау себепті мәзһабтарды жаңадан қайта қарастыруға мәжбүр жағдай туындаған. Ислам әлемінде жаңадан құрылған ағымдар негізінен дәстүр мен мәзһабтық ерекшеліктерін проблема ретінде қабылдап, осыларды сынау арқылы жаңаша бір кеңейе түсуді мақсат еткен. Алайда, салафияның радикал қабылдамаушы мұрагерлік әрекеті мәзһабтардың жағымды қырларын іздеген, олардың мәдени, күнделікті өмір мен әлеуметтік қырына деген оң ықпалдарына баса назар аударатын бір сананың қалыптасуына жол ашқан. Өйткені, мәзһабтар арасындағы бәсеке салафияның барынша шоғын қыздыра түскен соғысынан анағұрлым өлшемді әрі сыпайы көрінуде.

\section{Салафиттік парадигманы түсіну}

Салаф пен салафиттік ұғымдары жеңіл бір бірінің орнына қолданылып жүр. Ал анығында бұл екі ұғым арасында семантика болғандықтан, анағұрлым мағыналық айырмашылық бар. Семантикалық жақындық пен осыны тудырған белгісіздік салафи идеологияның осылай қалдырған бір жағдайы. Салафи сөздер қабылдамаған келесі бір ағымдардың салафиттік көзқарасқа қарауындағы белгілі бір үрку көзге байқалады. Бұл ассиметриялық әрі тепе теңдігі жоқ жағдай аталған ағымдардың танымындағы бостықтардан туындауда.

Ең баста салафи сөздер діни эпистемологиялық салада сафтықты, абыройлылықты, түп тамырды, алғашқы тәжірибені қасиеттегендіктен, оның бұл мәселедегі жанын салған ынталы әрекеті оны құрметті етіп, өзге ағымдардың алдында психологиялық басымдық беріп, олардың сыпайыгершілік сезімін тудырған болуы мүмкін. Тура бір «күнәмен былғану» және «бидғаттарды қорғау» тәуекеліне көз жұмып, салафиттермен күрес жүргізілмейтіндігі жолында шешімі күрделі белгісіз жағдай туындауда.

Ислам әлемінде салафиттікті тежеп отыратын күшті теологиялық тіл қалыптастырыла алмағандықтан, бұл мәселеде олқылықтар бар. Осы себепті салафиттік қозғалысқа қарсы бастамалар да аз уақыттың ішінде салафиттік қатаң сөздердің ықпалына ұшырап, соған ұқсас тәкпіршіл тілге жүгінуде. Сондықтан салафиттік қозғалыс тек міндетіне алған миссия мен көрсеткен тәжірибесімен емес, оған қарсылық танытқандарды да өзіне ұқсату себепті көпжақты ықпалға ие.

Осы салада ислам ойлау жүйесіне үлес қосу мақсатында жасалуы қажетті қадамдардың бірі кәлам мен философия қозғалысының заңдылығын қорғайтын мәтіндердің қайта еске түсірілуі әрі жаңаша тұжырымдалуы. Діни тақырыптарда ақылға жүгіну ұстанымына сүйенетін кәлам мен дін туралы тәуелсіз пікір өрбітуге сүйенетін философиялық қозғалыстың ислам дәстүріндегі орны қайта анықталуы тиіс. Бұл жұмыстар ақылды толықтай қабылдамайтын немесе оның барлық билігін қырқып тастайтын салафиттік идеологияның дін тұрғысынан қаншалықты орынсыз екенін байқауға мүмкіндік береді. Қазіргі уақытта Ислам ойлау жүйесі мен теологиясы ең әлсіз әрі ең консервативті жағымен дәріптелгендіктен, ислам әлемі дәл қазір бұндай кеңеюден мақұрым болып көрінуде. Оның үстіне тарихи әрі саяси жағдайлар типтік бір дағдарыс теологиясы болған салафиліктің күшеюіне үлес қосуда. Ислам ойлау жүйесінің бай мазмұнының әрі көптүрлілігінің айшықтала түсуіне кедергі келтіруде.

Салафиттердің аузындағы өзгелерде жоқ нәрсе не? Тарихтан және алғашқы мағынадан алыстағандықтың белгілі бір мөлшерде мойындалуы өзге ағымдардағы ерекшелік. Ал керісінше саф болу мен түп негізге байлану пікірі әрі осы пікірді кейіннен туындаған барлық нәрсеге сын ретінде қолдану салафиттік пікірлердің негізгі ерекшелігі. Осы себепті, ислам ойлау жүйесінде салафиттерге қарсы тепе-теңдіктен ауытқымайтын әрі көкейге қонымды пікір өрбіту уақыт талабы, бұл психологиялық теологиялық кедергіге ұшырауда. Өзіне тура бір бөлектеуші әрі құрметті ерекшелікті таңып алған салафизмге қарсы тұруға тырысқан кейбір бастамалар оның осы бір психологиялық теологиялық бөлекшелігі себепті тереңнен торығуды бастан кешеді. Әсіресе, Сунниттер мен мектептері үшін осы жағдай тұйықталу ретінде жалғасуда.

Түп негізге оралып, ғасырдың жамандықтарынан арылуды қалау пікірін әрдайым сергек ұстау, бір парадигма ретінде салафи идеологиясын да күн тәртібінде ұстауда. Miне, салафизмнің бір пікір ретінде жаңа заманғы идеология болып саналуының әрі осы қырымен қарастырулы керектігінің негізгі себебі осы. 
Негіз ретінде салафизмды қолдаушылардың басқа ислами тұжырымдарға қарауындағы қатал әрі дөрекіліктерінің астарында өзін исламның түп негізі ретінде қабылдау жатыр. Бұл - күтілген әрі табиғи нәтиже. Өйткені салафиттік идеологияның абсолютті әрі монополяшыл ерекшелігі барлық жағдайда сыпайылық таныту, келісімге келу, татулық, жұмсару, кері шегіну әрекеттерінің барлығын табанда ысырып тастауда. Неге десеңіз, бұлардың барлығы да діннен алыстау әрі оны кірлету әрекеттеріне деген еренсіздік, босаңсу әрі салғырттық ретінде саналады. Алғашқы Харижиттік топтардың бірі Азариканың өздерімен бірге болып, бірақ бірге соғысқа қатыспағандарды (қаада) кәпір деп санаудан тартынбауларының астарында да осы сенім жатыр. Өзін діни ақиқатпен бір санап әрі бұны нақты сенімге айналдырған ойлау жүйесін жүзеге асыруға болатын бір ғана белсенділік түpi жорамалға жабық түрде үзіліссіз күрес жүргізу. Сондықтан осы пікірдің саяси тұрғыдан мұсылман елдері үшін беретін мәні ішкі соғысты білдіреді.

\section{Салафизмнің (бұрынғы) салафтармен қа- тынасы: салаф салафи ма еді?}

Өзін қатал әрі қатаң түрде өткенмен байланыстырған әр сөз идеологияға айналуға мәжбүр. Идеология позитивті мағынада адамның мағына мен құндылық іздеуін, қалыптастыру талпынысының бір нәтижесі. Алайда, бұл үрдісте ішінде орын алған шындықпен болған қатынас үзілмеуде әрі іс пен баға қысымы бір жағдайда идеологияның сыни әрі жауапқа тартушы функциясымен тепе теңдігі реттелуде. Алайда, шындықтан бір рет ажыраса, ой мен шындық арасында туындаған қысым мен бұл тудырған күйреу, идеологияның ішке тұйықталуына жол ашуда. Шындықтан ажыраудан туған ашық, идеологиялық қаталдықпен жөнге келтірілуге әрекеттенуде. Барлық догматикалардың шындықтан әрі әлемдегі жек көрушіліктердің себебі осында жатыр. Әр жолы идеологияны өтірікке шығаратын әлем олардың ашуының нысанына айналуда. Идеалогияның мағына тудыратын жағы бұл жерде ең патологиялық түрде жұмыс істеуде. Неге десеңіз, өткен нәрсе дәл қазір жоқ. Ол шындық емес, қиял түрде ғана бар. Сол себепті, өткеннің өзін мақұлдағандығын алға тартқан сөз соған дәлел болатын айғақтарды қажет етеді.
Салафизм сөз етілгенде өткеннің, эклективті әрі редукционистік түрде әрі ең аңғал сөзге жақындатылғанын айтуымыз керек. Әсілі өзіне өткен шақтан орын іздеп, заңды етіп көрсеткісі келетін кепілдеме ретінде тарихқа сүйенетін барлық ой мен сенім салафиттік идеологияның жасағанын жасап, насстарға әрі алғашқы мұсылман ұрпақтардың тәжірибесіне негізделуде.

Мәдени және институционалды өзгерісті бақылауда ұстаған алғашқы кезеңдерде жорамал мен қиясты өте аз қажет еткен. Сол себепті салаф кезеңінде анықталмаған деген уәжбен мағынаны байыту әрі мектепке айналуға (философия, кәлам, тасаууыф секілді) қарсы шыққан әрі бұларды діннен адасу ретінде бағалаған салафи ұстаным қателікке бой алдыруда. Кәлам мен тасаууыф ойшылдарының әхлі хадистың қарсылықтарынан өздерін қорғау мақсатында жазған мәтіндердегі негіздемелер исламды адамзаттық тәлім етуге бағытталған айғақтардың орнын басуда. Кері жағдайда исламды жою үшін қалғаны күш қолдану мен қылышқа жүгіну таңдауы ғана қалуда. Онсыз да көне әрі жаңа салафи топтардың күш қолдануға бейім болуы - олардың осындай түсініктерінің табиғи нәтижесі.

Салафиттардың айтып жүргендеріне қарсы бұрынғы салафтар қазіргі салафи емес еді. Бұл - соларға қаратылған құлдырау кезеңінің көзқарасы. Қанша жерден салафизмнің айғақтарын қолдайтындай көріністерге кездессе де, алғашқы ұрпақтардың дін мен дүниені қабылдауы, насстардың жанында ақылды, қоғам пайдасы мен тәжірибені де өлшем етіп алған өзіне сенім сезіміне негізделген. Мемлекеттің бюрократиялық қажеттіліктерін өтеу мақсатында Иран саяси мәдениетінен диуан (кеңес) практикасын алып, жүзеге асырған хазірет Омар алғашқы кезеңде болмағандықтан, бұл мекемені жолға қойғанда Исламға жат іс жасадым деп ойламады. Оның бұл бастамасына сахабалар да қарсылық танытпады. Сондықтан салафияның алғашқы ұрпақтарға қатыстыра қалыптастырған салаф мәзһабының танымы осы қиялдан тұрады. Әрі тарихты теологиялық тұрғыдан қате оқудың бір нәтижесі. Бұған қоса, ықпалды болуының себебі, діни батырлықты әсірелеуіндегі жетістігі. Бұдан бөлек, кәлам, философия және сопылық мектептерінің кей уақыттар әсірелікке баратын жорамалдары тудырған күмән мен сенімсіздік те соған үлес қосқан. 


\section{Әдебиеттер}

1 Ahmet Akbulut, «Selefîliğin Teolojik ve Düşünsel Temelleri», Tarihte ve Günümüzde Selefîlik, İstanbul, 2014.

2 İbni Teymiyye el-Harrânî, el-Akîdedu'l-Vâsitiyye ve İhtiva Ettiği Yüce Mebâhise Dair Tenbihât, şerh: Abdurrahman b. Nasır es-Sa'dî, talik: Abdulaziz b. Abdillah b. Bâz, çev. Hüseyin Cinisli, İstanbul, 2013

3 İbni Teymiyye, Minhâcu's-Sünnet'i-Nebeviyye, Kahire, 1986

4 İmam-1 Azam Ebu Hanife, İmamı Azam Ebu Hanife ve Eserleri, «Osman el-Bettî̀ye Yazdığı Risale», çev. Abdulvvahhab Öztürk, İstanbul, 2012

5 İslam Ansiklopedisi, 'Selefîyye' md., cilt 36, İstanbul 2009

6 Muhammed b. İbrahim el-Hamed, Ehl-i Sünnet’in Seçkin Özellikleri, çev. Serkan Özgül, İstanbul, 2007

7 Muhammed bid el-Câbirî, Arap-İslam Siyasal Aklı, çev. Vecdi Akyüz, 2. Baskı, İstanbul, 2001

8 Mehmet Evkuran, «İslam'da Eşitlik ve İtibar Talebinin Teolojik Dili- Mukallidin İmanı ve İmanda İstisna Tartışmalarının Sosyo-politik ve Kültürel Bağlamı», Uluslararası İmam Maturidi ve Maturidilik Sempozyumu, http://www.bilgelerzirvesi.org/bildiri/maturidi/Prof-Dr-Mehmet-EVKURAN.pdf

9 Mehmet Evkuran, Sünnî Paradigmayı Anlamak-Bir Ekolün Politik ve Teolojik Yapılanması, Ankara, 2. Bask1, 2015

10 Mehmet Zeki İşcan, Selefîlik-İslamî Köktenciliğin Tarihî Temelleri, 2. Bask1, İstanbul, 2009

11 Osman Ali Hasan, Kavâidu'l-İ'tikâd alâ Mesâlihi'l-İtikâd, Dâru'l-Vatan, 1992

12 Süleyman Uludağ, İslam Düşüncesinin Yapısı, İstanbul, 1976

13 1eş-Şemsu's-Selefî el-Efgânî, A'dâu'l-Mâturidiyye li'l-Akîdeti's-Selefîyye, Peşaver, 1998

14 Sefer b. Abdurrahman el-Havalî, Mürcie İnancı ve İslam Ümmeti Üzerindeki Kötü Tesirleri, çev. Ebu Abdurrrahman Azadi, İstanbul, 2012

15 Tarihte ve Günümüzde Selefîlik, Ed. Ahmet Kavas, Ensar Yayınları, İstanbul 2014 